\title{
Job Characteristics and Person-Job-Fit as Predictors of Nigerian Military Personnel Career Adaptation
}

\author{
Ikechukwu V. N. Ujoatuonu ${ }^{1}$, Chiedozie O. Okafor ${ }^{2 *}$, Gabriel C. Kanu ${ }^{1}$, Chidiogo J. Okeke ${ }^{1}$
}

${ }^{1}$ Department of Psychology, Faculty of the Social Sciences, University of Nigeria, Nsukka, Nigeria

${ }^{2}$ Department of Psychology, Alex Ekwueme Federal University Ndufu-Alike, Ebonyi State, Nigeria

DOI: $10.36347 /$ sjahss.2020.v08i12.003

| Received: 14.12 .2020 | Accepted: 22.12.2020 | Published: 30.12.2020

*Corresponding author: Chiedozie O. Okafor

Abstract

The seemly ethno-religious classified operations and unconstitutional political participation of the Nigerian military also seem to have always influenced their job characteristics, career adaptation, person-job-fit and modus-operandi. Our study investigated job characteristics and person-job-fit as predictors of Nigerian military career adaptation based on Theory of Purposeful Behaviour. The participants for our study comprised of (199) Military personnel drawn through purposive sampling method. Three instruments; Job Characteristics Scale, Person-Job-Fit Scale and Military Career Adaptability Questionnaire were used and multiple regression employed for data analysis. Result of our study showed that job characteristics were not significant predictor of military career adaptability; person-job-fit was a significant positive predictor of Nigerian military career adaptation. The result of our study implies that soldiers need special individual abilities (person-job-fit) to solve internal threat issues (e.g., Boko Haram, Fulani herdsmen resurgences', armed banditry, political and religious uprising challenges) and adapt to military career. Our research deepened the existing body of knowledge on military career adaptation by integrating person-job-fit and job characteristics of Nigerian military with psychology of work. We recommend that to help Nigerian military personnel adapt to their career, it is important not to provide non-ethnic defense militia, intergroup discrimination, psychosocial organizational conflict, but rather grant work method control to Nigerian defense organizations. However, more research is needed on vital psychological states of soldiers such as work/non-work interference and enhancement, motivation profiles, person-organization-fit and perceived work ability for further clarification of military career adaptation generally and particularly in Nigeria.

Keywords: Career adaptation; job characteristics; Nigerian military; person-job-fit; psychology of work.

Copyright $(\mathcal{C} 2020$ The Author(s): This is an open-access article distributed under the terms of the Creative Commons Attribution 4.0 International License (CC BY-NC 4.0) which permits unrestricted use, distribution, and reproduction in any medium for non-commercial use provided the original author and source are credited.

\section{INTRODUCTION}

There is a growing awareness that Nigerian $4^{\text {th }}$ republic governments (i.e., transformation of military leaders born out of military politics to democracy) are not taking security intervention policies seriously [1]. This reluctant security intervention policies has affected the level of adaptability of our Joint Task Force Operatives [2], and army in particular in the fight against terrorism, Boko Haram and Fulani Herdsmen resurgences' [3], kidnapping, armed banditry, political and religious uprising [4]. As observed in Nigeria, these has lead to altered job characteristics, lack of job crafting, work/non-work interference and enhancement [5], organizational identity [6] with [7] career adaptation issues, doubtfulness of work ability [8] and the resignation of over three hundred and fifty six (356) military personnel in the midst of insecurity challenges facing the country. This has made every Nigerian soldier to have a rethink and reflect on the ideological and psychological conditions of cognitive ability and career adaptation in the face of challenges, conflicts and battlefield. Yet, military career adaptability represents extraordinary job-related assemblage of soldiers through organization, fusion, communication, learning development and emotion regulation abilities; Zhang, $\mathrm{Xu}$, Peng, Bian, Yu, Li, \& Li [9], with interconnected mental health and work efficiency for fighting competence in face of insecurity challenges, conflicts and warfare.

The Theory of Purposeful Behavior [10] embodies current advancement in the interactional approach and analysis of military personnel job-related behavior during insecurity conflicts, challenges and warfare. This theory implies that individuals readjust to redesigned verbal command, job characteristics plus demands and work method control outcomes during challenges, conflicts and warfare [11]. Researchers [10, $12,11]$ also narrated how purposive behavior through 
personal dispositions (person-job-fit) and situational factors (job characteristics) influences work-related behavior (career adaptation) and performance of military personnel. Barrick and colleagues also stated that when personal dispositions, situational factors and motivations connected to career goals are sustained by job characteristics, a psychological condition of meaningfulness, thriving at work, psychological attachment, perceived work ability and career adaptation is achieved.

Reports of interviews, observations and studies [13-15] has shown that Nigerian defense organizations has been infiltrated by an Islamic sect which has politicized, imposed unwritten job characteristics, elevated ethno-religious militia in the management teams for redesigned work method control and dictatorial nature. As observed, this crisis, conflicts, resurgences and COVID-19 period has been used as a perfect time to alter organizational identity and career transitions of Nigerian soldiers [6], job characteristics, perceived fit/misfit of Nigerian military personnel and termed situational decree for military strategicmanagement abilities. Nigerian military organization management with ethnocentric, stereotypic and stanch religious politicians in government now redefines written established job characteristics, perceived job-fit and individuality of military personnel according to their relationship with them [4]. As observed, relationship with Nigerian defense management and politicians now ascertain the right soldier, assignment and whom to include in conflict, drawdown, growth and combat scenes. This has given rise to negative impact on the fight against resurgences, armed banditry, Boko Haram and Fulani Herdsmen as a result of loss of right people to the right job (perceived fit). However, our study concentrated on one of the dimensions of perceived fit which is (person-job-fit). Person-job-fit is tied to soldiers work ability in general, career, job need and interests.

Nigerian military personnel person-job-fit as stated by [16] means congruence between what the soldiers now brings to table of ethno-religious defense management and political party in power. It is not determined by what the job needs are and if the soldier's abilities matches those needs. This means that soldiers seeming job demand-abilities-fit has been altered over time $[8,17]$, by virtue of political party in power and ethno-religious defense management. In all, person-job-fit is needed in defense organizations facing insecurity challenges and conflicts as it influences motivational traits and job satisfaction [18], proactive career behavior [19], performance [20], vocational interest and job assignment [21], dark traits of combatants with unethical attitudes and conduct [22] while aiding career adaptation. Based upon the prior research findings, we therefore hypothesized that:

H1 Job characteristics will negatively predict Nigerian military career adaptation.
H2 Person-job-fit will positively predict Nigerian military career adaptation.

\section{METHOD \\ Participants and Procedure}

One hundred and ninety nine (199) soldiers (150 males \& 49 females) whose age ranged from 25 59 years $(M=44.33$; $S . D=7.19)$ participated in this study. Participants were approached at their divisions or base by the researchers after permission was granted by the General Officer Commanders (GOCs) of the Nigerian Army to conduct the study. Interested soldiers from eight directorates such as Training and Operations, administration, Army Board of Inquiry, army logistics, army standards and evaluations, civil-military cooperation's, policy and plans, army reserve recruitment and resettlement rear, gave consent and were given copies of the questionnaires to fill. The researchers explained the nature of the study to the participants, what they were required to do, confidentiality with their personal information and informed them of free withdraw at any stage of the study, without any prejudice. They were also encouraged to answer the questions as honestly as possible and it was observed that the length of the measures items was not a problem. The distribution of the questionnaire took three weeks and six days.

\section{MEASURES \\ Military Career Adaptability Questionnaire}

The Military Career Adaptability

Questionnaire was developed by Zhang, Xu, Peng, Bian, $\mathrm{Yu}$, and $\mathrm{Li}$ [9] as a self-report effective tool to measure the career adaptability of military personnel. The questionnaire has 21 items with five factors that include: organization and fusion ability (management system and specification, management mode, professional pride, spirit of sacrifice, teamwork, and perseverance, reflecting the relationship between individuals and organizations, named organization and fusion ability), communication ability (interpersonal relationships, comrade-in-arms communication, superior and subordinate relationships, loneliness, and family communication, which reflected the relationships between individuals and others, named communication ability), learning development ability (professional knowledge, learning ability, selfawareness, and command ability, reflecting the relationship between individuals and work, named learning ability), emotion regulation ability (work stress, environmental change, work frustration, and closed environment, reflecting the relationship between individuals and the work environment, named emotion regulation ability), and career transformation ability (job change, secondary employment, career expectation, and emergencies, reflecting the relationship between individuals and their career, named vocational transformation ability). The MCAQ is measured on a seven-point Likert scale format ranging from 1 to 7 with internal consistency coefficient of 0.92 [9]. The 
KMO value of sampling adequacy was 0.90, and Bartlett's test for sphericity showed a significant difference $(p<0.001)$ [9]. We obtained Cronbach's alpha $(\alpha)$ of .91 , from a pilot study conducted to validate the Military Career Adaptation Questionnaire for the present study with a sample of 86 Nigerian military personnel's drawn from the 3 Armored Division HQ located in Jos, Plateau State.

\section{Job Characteristics Questionnaire}

The Job Description Survey (JDS) was developed by Hackman and Oldham [23] based on a theory of how job design affects work motivation and offers measures of (a) job dimensions, (b) individual psychological states (c) affective reactions of employees to the job with work setting and (d) individual growth need strength. The core job characteristics are skill variety (the degree to which a job requires various activities); task identity (the degree to which the job requires workers to identify and complete a piece of work with a visible outcome); task significance (the degree to which the job impacts other people's lives); autonomy (the degree to which the job provides the employee with freedom, independence, and the option to plan work and regulate procedures in the job); and feedback from job itself (The degree to which the workers are provided with clear, specific, detailed, information about the effectiveness of their job performance). The three basic psychological critical states theoretically promote high performance, motivation, and satisfaction at work. The critical states are that a person must experience the work as meaningful, valuable, and worthwhile and feel responsibility for the result of the work and, finally, that a person should have knowledge of the results of the work. Sample item include; "In this job, the available instructions related with the job remain unclear and insufficient." "It becomes problematic for me to establish coordination between political and group pressure and formal principles." We obtained Cronbach's alpha $(\alpha)$ of .71, from a pilot study conducted to validate the Job Characteristics Scale for the present study with a sample of 86 Nigerian military personnel's drawn from the 3 Armored Division HQ located in Jos, Plateau State.

\section{Person-Job-Fit Scale}

The Global Self-Report Measure of Person-Job Fit consists of 9 items developed by Brkich, Jeffs and Carless [24], to measure how an employee's current job matches their goals, needs, abilities, skills, talents, competencies and motivation. The scale is measured on a seven point Likert-scale ranging from 1=strongly disagree to $7=$ strongly agree. Sample items include; "My current job is really me." "I am able to use my skills, talents and competencies in my current job." Brkich, Jeffs and Carless [24] obtained an internal consistency of .92 while we obtained Cronbach's alpha $(\alpha)$ of .93 , from a pilot study conducted to validate the Person-Job-Fit Scale for the present study with a sample of 86 Nigerian military personnel's drawn from the 3 Armored Division HQ located in Jos, Plateau State

\section{DATA ANALYSIS}

Pearson's correlations was used to establish the relationships of the study variables including some relevant demographic factors. Hierarchical multiple regression was used to analyze the data in order to test the hypotheses in Statistical Package for Social Sciences (SPSS $®$ ) version 20. Multiple regression analysis was used to analyze several predictor variables, and is in a position to explain better the variation in the dependent variable, and hence make more accurate predictions [25, 26]. Regression is important in establishing the linkages between (a) scores on different tests, (b) test scores and non-test (demographic) variables, (c) scores on parts of tests and scores on whole tests, etc [27].

\section{RESULTS}

The summary of our results showed that descriptive statistics is made known in Table 1; correlations of the demographic variables and study variables in Table-2, while findings of the regression analysis are in Table-3.

Table-1: Descriptive statistics for Age and the study variables

\begin{tabular}{|l|l|l|l|}
\hline Variables & Range & Mean & Std. Deviation \\
\hline Age & $25-59$ & 44.33 & 7.19 \\
\hline Job characteristics & $37-84$ & 60.86 & 9.25 \\
\hline Person-job fit & $22-56$ & 41.83 & 8.44 \\
\hline Military Career adaptability & $17-59$ & 40.21 & 6.91 \\
\hline
\end{tabular}

Descriptive statistics in Table-1 showed that employment status range of the participants was from 25-59 years $($ Mean $=44.33, \mathrm{SD}=7.19$ years $)$. The scores of the participants on the variables in the study were within the normal range of scores. 
Table-2: Correlations of demographic variables, job characteristics, person-job fit and military career adaptability

\begin{tabular}{|l|l|l|l|l|l|l|l|l|l|}
\hline Variables & $\mathbf{1}$ & $\mathbf{2}$ & $\mathbf{3}$ & $\mathbf{4}$ & $\mathbf{5}$ & $\mathbf{6}$ & $\mathbf{7}$ & $\mathbf{8}$ \\
\hline 1 & Age & - & & & & & & & \\
\hline 2 & Gender & $.32^{* * *}$ & - & & & & & & \\
\hline 3 & Number of children & $.44^{* * *}$ & $.25^{* * *}$ & - & & & & & \\
\hline 4 & Number of dependent & $.53^{* * *}$ & $.22^{* *}$ & $.42^{* * *}$ & - & & & & \\
\hline 5 & Years of service & $.70^{* * *}$ & $.33^{* * *}$ & $.45^{* * *}$ & $.39^{* * *}$ & - & & & \\
\hline 6 & Educational qualification & $.41^{* * *}$ & $.29^{* * *}$ & $.33^{* * *}$ & $.40^{* * *}$ & $.28^{* * *}$ & - & & \\
\hline 7 & Job characteristics & -.07 & $-.14^{*}$ & -.01 & -.07 & $-.34^{* * *}$ & .02 & - & \\
\hline 8 & Person-job-fit & -.04 & .12 & .08 & .12 & $-.19^{* *}$ & $.22^{* *}$ & $.22^{* *}$ & \\
\hline 9 & Military career adaptability & -.07 & -.12 & -.01 & $.19^{* *}$ & $-.32^{* * *}$ & -.03 & .12 & $.50^{* * *}$ \\
\hline
\end{tabular}

Note: ${ }^{*} \mathrm{p}<.05^{* *} \mathrm{p}<.01 ;{ }^{* * * *} \mathrm{p}<.001 ;$ Gender $(1=$ Male; $0=$ female $)$;

In Table-2, older age was associated with male gender $(r=.32, p<.001)$, more number of children $(r=$ $.44, \mathrm{p}<.001)$, more number of dependent $(\mathrm{r}=.53$, $\mathrm{p}<.001)$, more years of service $(\mathrm{r}=.70, \mathrm{p}<.001)$, and higher educational qualification $(\mathrm{r}=.41, \mathrm{p}<.001)$. Female gender was associated with more number of children $(\mathrm{r}=.25, \mathrm{p}<.001)$, had more number of dependent $(r=.22, p<.01)$, had more years of experience $(\mathrm{r}=.33, \mathrm{p}<.001)$, higher educational qualification $(\mathrm{r}=.29, \mathrm{p}<.001)$, and less affected by job characteristics $(r=-.14, p<.05)$. Higher number of children was associated with higher number of dependent $(\mathrm{r}=.42, \mathrm{p}<.001)$, more years of service $(\mathrm{r}=$ $.45, \mathrm{p}<.001)$, and higher educational qualification $(\mathrm{r}=$
.33 , p <.001). Higher number of dependent was associated with more years of service $(\mathrm{r}=.39, \mathrm{p}<.001)$, higher educational qualification $(\mathrm{r}=.40, \mathrm{p}<.001)$, and high military career adaptability $(\mathrm{r}=.19, \mathrm{p}<.01)$. Those who had more years of experience had higher educational qualification $(\mathrm{r}=.28, \mathrm{p}<.001)$, were less affected by job characteristics $(\mathrm{r}=-.34, \mathrm{p}<.001)$, had less person-job fit $(\mathrm{r}=-.19, \mathrm{p}<.01)$, and less military career adaptability $(\mathrm{r}=-.32, \mathrm{p}<.001)$. Still, higher educational qualification was associated with more person-job fit $(\mathrm{r}=.22, \mathrm{p}<.01)$ and job characteristics was positively associated with person-job-fit $(\mathrm{r}=.22$, $\mathrm{p}<.01)$

Table-3: Hierarchical multiple regression predicting military career adaptability, by number of dependent, years of service, job characteristics and person-job fit

\begin{tabular}{|c|c|c|c|c|c|c|c|c|c|}
\hline \multirow[t]{2}{*}{ Predictors } & \multicolumn{3}{|c|}{ Step 1} & \multirow[b]{2}{*}{$\mathbf{B}$} & \multicolumn{2}{|c|}{ Step 2} & \multicolumn{3}{|c|}{ Step 3} \\
\hline & B & $\beta$ & $\mathbf{t}$ & & $\boldsymbol{\beta}$ & $\mathbf{T}$ & B & $\beta$ & $\mathbf{t}$ \\
\hline Number of dependent & 4.20 & .37 & $5.36^{* * * *}$ & 4.21 & .37 & $5.34^{* * *}$ & 3.21 & .28 & $4.43^{* * * *}$ \\
\hline Years of service & -3.97 & -.47 & $-6.74^{* * * *}$ & -4.01 & -.47 & $-6.37^{* * * *}$ & -3.26 & -.38 & $-5.66^{* * * *}$ \\
\hline Job characteristics & & & & -.01 & -.01 & -.18 & -.06 & -.08 & -1.26 \\
\hline Person-job fit & & & & & & & .33 & .41 & $6.79^{* * * *}$ \\
\hline $\mathrm{R}^{2}$ & \multicolumn{3}{|l|}{.22} & \multicolumn{3}{|l|}{.22} & \multicolumn{3}{|l|}{.37} \\
\hline$\Delta \mathrm{R}^{2}$ & \multicolumn{3}{|l|}{.22} & \multicolumn{3}{|l|}{.00} & \multicolumn{3}{|l|}{.15} \\
\hline $\mathrm{F}$ & \multicolumn{3}{|c|}{$27.08(2,193)^{*}$} & \multicolumn{3}{|c|}{$17.98(3,192)^{* * *}$} & \multicolumn{3}{|c|}{$28.18(4,191)^{k * * *}$} \\
\hline$\Delta \mathrm{F}$ & \multicolumn{3}{|c|}{$27.08(2,193)^{*}$} & \multicolumn{3}{|c|}{$.03(1,192)$} & \multicolumn{3}{|c|}{$46.11(1,191)^{* \cdot 1}$} \\
\hline
\end{tabular}

${ }^{* * *} \mathrm{p}<.001 ; \Delta \mathrm{R}^{2}=$ Change in $\mathrm{R}^{2} ; \Delta \mathrm{F}=$ Change in $\mathrm{F} ; \mathrm{B}=$ Unstandardized regression coefficient; $\beta=$ Standardised regression coefficient

Results of the hierarchical multiple regressions for the test of the hypotheses are shown in Table-3. In Step 1 of the regression model, number of dependent and years of service were added to the regression model because of their significant relationship with military career adaptability in the correlations. Number of dependent positively predicted military career adaptability, $\beta=.37, \mathrm{t}(199)=5.36, \mathrm{p}<.001$. The unstandardized regression coefficient (B) showed that for every one unit increase in number of dependent, military career adaptability rises by 4.20 units. Years of service negatively predicted military career adaptability, $\beta=-.47, \mathrm{t}(199)=-6.74, \mathrm{p}<.001$. The unstandardized regression coefficient (B) showed that for every one unit increase in years of service, military career adaptability decreases by 3.97 units. The control variables contributed $22 \%$ in explaining the variance in military career adaptability $\left(\mathrm{R}^{2}=.22\right)$, and the model was significant, $\mathrm{F}(2,193)=27.08, \mathrm{p}<.001$.

In step 2, job characteristics were added in the regression model. It was not a significant predictor of military career adaptability, $\beta=-.01, \mathrm{t}(199)=-.18$. The contribution of job characteristics in explaining the variance in military career adaptability was $0 \%\left(\Delta \mathrm{R}^{2}=\right.$ $.00)$, and the model was not significant, $\Delta \mathrm{F}(1,192)=$ .03 .

In step 3, Person-job fit was added in the regression model. It was a significantly positive 
predictor of military career adaptability, $\beta=.41, \mathrm{t}$ (199) $=6.79, \mathrm{p}<.001$. The unstandardized regression coefficient (B) showed that for every one unit increase in Person-job fit, military career adaptability increases by .33 units. The contribution of person-job fit in explaining the variance in military career adaptability was $15 \%\left(\Delta \mathrm{R}^{2}=.15\right)$, and the model was significant, $\Delta \mathrm{F}(1,191)=46.11, \mathrm{p}<.001$. The strongest predictor of military career adaptability in the present study was years of service $(\beta=-.47)$, and all the predictor variables in the study accounted for $37 \%$ of the variance in military career adaptability $\left(\mathrm{R}^{2}=.37\right)$.

\section{DISCUSSIONS}

Our study investigated job characteristics and person-job-fit on Nigerian military personnel career adaptation. Two hypotheses were tested. The result of the first hypothesis showed that job characteristics were not a significant predictor of Nigerian military personnel career adaptability. Thus, the first hypothesis was confirmed. This result can be attributed to our observed redesigned nature of Nigerian military job characteristics and democratization of the defense organization by politicians. None of the five core features of job characteristics (skill variety, task significance, task identity, autonomy and feedback from the job itself) predicted military career adaptation. Even task significance as expected to predict and serve as a suppressor factor to military career adaptation had no relationship. This means that authorities' interfere with work method control [28], work life balance policies, workplace supports [29] and job characteristics which in turn influence military career adaptation [15]. Since soldier's suggestions are not considered and policies on task significance, workplace support, work method control with job descriptions are no longer implemented [8].

Furthermore, Nigerian soldiers do not get appropriate wages for extra work done and do not have sufficient opportunity for promotion after developing their skills plus ability; except when they are from a particular region, religion, ethnicity, related to the present service chief and political party in power $[1$, 11]. The political and ethnocentric procedure for enlistment into the Nigerian military with appraisal and rank structure which is not determined by federal law has given rise to numerous split of unrelated sets of soldiers with work/non work interference and enhancement [8], which has altered their job characteristics, perceived fit and ability [1], operational irregularities and career adaptation [30]. As they are enlisted and/or recruited, run and appraised differently, through unusual performance principles, serve in special divisions with conditions distinct from soldiers enlisted through undiluted defense procedures, programs and practices [31]. This is done through redesigned ethnocentric military work fixing (e.g., enlisting Boko Haram; Eneche, 2020, June 11 and Fulani Herdsmen members into the military [32]; The
Defense Post 2019 [3]; John, 2014 [14]), political party in power institutional enlistment process redesign, ethnic, religious and cultural identity threat by classified northern government cabinet creating ethnic divisive militias [13]. Also, Nigerian military has been domesticated and their resources with operations controlled by a particular unclassified political cabals [31]. The political party in power with their significant others has within a short period changed Nigerian military organizational, operational and warfare structure to contain their mission-based desires and job characteristics altered [11].

Recently as observed from 2015-date, all aspects of Nigerian military missions, structure, confronting insecurity challenges and conflicts and role including acquisition of weapons and other equipments are openly controlled by significant elements in government and superior classified political office holders [5] rather than determined exclusively by the defense organization which has altered defense organizational job characteristics. Though the management of the defense organization is consulted, yet, key and tactical resolutions are determined by government and party in power who are often prepared for extra organizational precedence, job characteristics and pressures [4]. Interviews granted by some Nigerian military personnel accepted organizational tasks, job descriptions and characteristics are ruled by huge set of superficially forced difficult set of policies; planned for other political reasons and party organization.

The financial plan of Nigerian military is forced from external, even to the position of subcategory requirement and weapons $[33,34]$. Since this financial plan is not straightforwardly connected to defense organizational act or consented for unambiguous agenda or operations that have supreme precedence for these significant persons in government yet $[33,16]$, they would never be cancelled nor postponed). This has shown that the provision of defense organization funds and fight against insecurity challenges if for their clear-cut agenda or operations by these politicians which alters soldier's job characteristics and career adaptation $[8,33]$.

The second hypothesis was confirmed as person-job fit was found to be a significant positive predictor of military career adaptability. This established fact that person-job fit was associated with higher military career adaptability [35], which could help with soldier's wellbeing and flourishing in the face of security challenges and conflicts [17]. This result broadens the viewpoint embedded in Theory of Purposeful Behaviour that perceived fit [10] could possibly help equip Nigerian soldiers with selfregulatory abilities to deal with demanding circumstances like altered job characteristics, security challenges and conflicts [36]. This can be ascertained from our result on the positive relationship between 
higher education, job characteristics and person-job-fit on Nigerian military personnel career adaptation.

Specifically, when soldiers are highly educated, with detribalized service chiefs, cabals and political party in power, they can easily maneuver their tainted job characteristics to aid person-job-fit and career adaptation. Since higher education aid personjob-fit and job characteristics, our finding other additional confirmed studies [37, 35, 38, 31, 39, 17, 40] suggesting that person-job-fit leads and carves career adaptability reactions or displays. These empirical studies revealed the relevance of person-job-fit, job characteristics and career adaptation careers, work settings, security challenges and conflicts. On the other side of the continuum, theory of purposeful behavior suggests that the career adaptation process is driven by adapting to the job characteristics with the goal of person-job-fit [10].

\section{IMPLICATIONS OF FINDINGS}

The insinuation of our study result is complex, yet, with significant implications for Nigerian defense organizations, career management, human resources and counselor in psychological affairs of military organizations. Since having numerous discrete soldiers with different perceptions of job characteristics and person-job-fit while trying to adapt to their career cannot help completely to fight security challenges. However, our results may help to design interventions and policies to align with the resources such as concern, control, curiosity and confidence while resolving Nigerian soldiers job characteristics issues.

Additionally, from our findings and happenings in Nigeria, we envisage strikes, mutiny, face-offs, collective bargaining, increased unilateral turnover intentions, protests, unlimited voicing of dissatisfaction publicly, lower organizational identity, resignation without permission, and other negative work attitudes with outcomes among Nigerian military personnel soon; since they are at the end of their terms. Our study could possibly aid Nigerian defense organizations, policy makers, industrial psychologists and other government key knowledge regarding the psychological pathways and variables that connect military career adaptability, job characteristics and person-job-fit. With the evidence presented in this study, significant persons and organizations concerned will be able to appreciate the functional mechanism through which military personnel can reduce perceptions of job characteristics and military career adaptability.

Acquiring key weapon systems, mode of an unrelenting action during combat deployment and exposure, personnel enlistments with opening or closing of military base should not be based on economic or political interest, rather on selflessness and wholly on military efficiency. Our findings in this aspect suggests that in order to make use of the best intervention strategies, significant persons and organizations may also consider an autonomous classified committee made of up military fanatics to generate intelligence on weapon procurement and delivery, mode of an unrelenting action during combat deployment and exposure, personnel enlistments with opening or closing of military base.

\section{LIMITATIONS AND FUTURE RESEARCH DIRECTIONS}

Despite the theoretical and practical implications elaborated above, several limitations should be addressed in future research. First, the employment of a cross-sectional design prevented further inferences regarding the causal relationships between military career adaptability, job characteristics and fit perception. Since the cross-sectional design is not able to exclude empirically potential reciprocal effect of the study variables on each other. Future research may use experimental or longitudinal studies to confirm causality. Second, the questionnaires were completed using a self-report format at the same time point which may possibly cause common method bias. Although our study results to some extent reduced this concern, but we suggest future researchers to collect multi-source or multiwave data as a way to address common method bias. Third, different types of personjob fit (e.g., needs-supply fit and demand-ability fit) were not considered. The consideration of overall person-job fit may only partially capture the underlying the relationship between military career adaptability and person-job-fit. Future studies should incorporate both needs-supply fit and demand-ability-fit to help obtain a fuller understanding of how person-job-fit may help manage military career adaptation issues.

Specifically, our findings demonstrated that highly adaptable soldiers are more likely to perceive fit between colleagues and/or teams with their jobs and organizations, which in turn has lead them to be embedded in their profession amid altered job characteristics. In practice, these findings might possibly offer military psychological services career counsellors innovative strategies drawn from military career adaptability resources to deal with job characteristics and person-job-fit. We recommended future researchers to continue to explore approaches to manage military job characteristics, particularly those unexplored mediation pathways and possible contingent conditions for the relationship between military career adaptability and job characteristics, person-job-fit, workplace support and perceived work abilities.

\section{RECOMMENDATIONS}

Our study recommends more research on Nigerian military personnel person-organization-fit, perceived work ability, thriving at work, combat exposure and experiences, work/non-work interference and enhancement, career identity and motivation. Also, 
the assumed minority soldiers (personnel from the south-east part of the country) need to make a case, request for change and/or expose the culprits with facts to the public and should cease from practicing enclosed system of organizational programs, practices and policies. Nigerian defense organization transformation should be encouraged through unit systematic restructuring and political command abolished or restructured. Nigerian combatant military personnel should receive constant mandatory special warfare compensation for life threats from combat exposures plus experiences or perilous responsibility pay authorized during this warfare, resurgences' and challenging period. Autonomous Nigerian military decisions devoid of political party and government in power affiliations or be politically associated with military tactics or efficiency.

\section{REFERENCES}

1. Eminue O. Military in politics. Akwa Ibom, Uyo: Soul Publishers. 2006.

2. International Crisis Group. Nigeria: The challenge of military reform. 2016. https://www.crisisgroup.org/africa/westafrica/nigeria/nigeria-challenge-military-reform. Accessed 7th June, 2020.

3. The Defense Post. Nigeria's military struggles with Islamic State: Part 2 - Systemic issues hamper the fight. 2019. https://www.thedefensepost.com/2019/01/25/niger ia-military-struggles-islamic-state-iswa-part-2systemic-issues/. Accessed 8th June, 2020.

4. Omenma JT, Onyishi IE, Okolie A. Correction to: A decade of Boko Haram activities: the attacks, responses and challenges ahead. Security Journal. 2020. doi:10.1057/s41284-020-00243-5.

5. Maikomo JM, Ngomba J. Military security issues (MSIs) and the challenge of internal security operations (ISOPs) in Nigeria. International Affairs and Global Strategy, 2018; 62:12-23.

6. Ujoatuonu IVN, Onyishi AB, Okafor CO, Amazue LO, Umeh CK. Organizational Identity and Career Transition as predictors of pre-retirement anxiety among Nigerian military personnel. Journal of Social Sciences \& Humanities, 2020; 5(2):74-90.

7. Ujoatuonu IVN, Kanu GC, Apeh OK. Vocational identity of Nigerian army personnel: Roles of spirit at work and energy at work. Nigerian Journal of Psychological Research, 2017; 13:4148.

8. Epiphany A. Military in internal security operations: Challenges and prospects. A paper presented at the Nigerian Bar Association 53rd Annual Conference 28th August, 2013, Tinapa Calabar, Nigeria. 2013.

9. Zhang, W., Xu, Y., Peng, L., Bian, C., Yu, Y., Li, Y., \& Li, M. (2020). Military Career Adaptability Questionnaire in China: Development and Validation. Frontiers in Psychology, 11(280), 1-9.
10. Barrick MR, Mount MK, Li N. The theory of purposeful work behavior: The role of personality, higher order goals and job characteristics. Academy of Management Review, 2013; 38, 132153.

11. Osterberg J, Rydstedt LW, Kleiven J, Brandebo MF. The path of job satisfaction. Applying the theory of purposeful behavior to military conditions. Journal of Defense Resources Management, 2017; 8(1), 27-42.

12. Österberg J, Rydstedt L. Job satisfaction among Swedish soldiers: Applying the Job Characteristics Model to newly recruited military personnel. Military Psychology, 2018; 30(4), 302-310.

13. Joab-Peterside $\mathrm{S}$. On the Militarization of Nigeria's Niger Delta: The Genesis of Ethnic Militia in Rivers State. Working Paper No. 21 12: 3 \& 4 October. Port Harcourt: Centre for Advance Social Science (CASS). 2007.

14. John E. The Fulani herdsmen in Nigeria: Questions, Challenges, Allegations. Available: www.elnathanjohn.blogspot (Accessed June 25, 2020). 2014.

15. Ugwueze MI, Onuoha FC. Hard versus soft measures to security: Explaining the failure of counter-terrorism strategy in Nigeria. Journal of Applied Security Research, 2020; 15(3):1-18.

16. Okoli AC, Orinya S. Evaluating the strategic efficacy of military involvement in internal security operations (ISOPs) in Nigeria. IOSR Journal of Humanities and Social Science (IOSRJHSS), 2013; 9(6), 21-23.

17. Sørlie HO, Hetland J, Dysvik A, Fosse TH, Martinsen ØL. Person-Organization Fit in a military selection context. Military Psychology, 2020; 1-10. doi:10.1080/08995605.2020.1724752

18. Lim S, Lee KH, Bae KH. Distinguishing motivational traits between person-organization fit and person-job fit: testing the moderating effects of extrinsic rewards in enhancing public employee job satisfaction. International Journal of Public Administration, 2019; 42(12), 1-15.

19. Sylva H, Mol ST, Den Hartog DN, Dorenbosch L. Person-job fit and proactive career behavior: a dynamic approach. European Journal of Work and Organizational Psychology, 2019; 28(5), 1-15.

20. Drasgow F. Prediction of performance by noncognitive traits. Military Psychology, 2020; 32(1), 127-134.

21. Kirkendall CD, Nye CD, Rounds J, Drasgow F, Chernyshenko OS, Stark S. Adaptive vocational interest diagnostic: Informing and improving the job assignment process, Military Psychology, 2020; 32(1), 91-100.

22. Lindén M, Björklund F, Bäckström M, Messervey D, Whetham D. A latent core of dark traits explains individual differences in peacekeepers' unethical attitudes and conduct. Military Psychology, 2019; 111. doi:10.1080/08995605.2019.1671095. 
23. Hackman JR, Oldham GR. Development of job diagnostic survey. Journal of Applied Psychology, 1975; 60, 159-170.

24. Brkich M, Jeffs D, Carless SA. A Global selfreport measure of Person-Job Fit. European Journal of Psychological Assessment, 2002; 18(1), 43-51.

25. Tabachnick BG, Fidell LS. Using multivariate statistics. Pearson, Boston. 2013.

26. Mendenhall W, Beaver, RJ, Beaver BM. Introduction to probability and statistics. Belmont, CA: Brooks/Cole, Cengage Learning. 2009.

27. Urbina S. Essentials of behavioral science series. Essentials of psychological testing. John Wiley \& Sons Inc. 2004.

28. Sieff K. The Nigerian military is so broken, its soldiers are refusing to fight, The Washington Post, May 10. 2015. https://www.washingtonpost.com/world/afri ca/the-nigerian-military-is-so-broken-its-soldiersare-refusing-to-fight/2015/05/06/d56fabac-dcae11e4-b6d7-

b9bc8acf16f7_story.html?noredirect=on\&utm_ter $\mathrm{m}=. \mathrm{a} 62 \mathrm{f} 9 \mathrm{eb} 7 \mathrm{ccaf}$. Accessed 30th March, 2020.

29. Ujoatuonu IVN, Kanu GC, Ugwuibe OC, Mbah OP. Role of Workplace support on the relationship between perceived work life balance policies and flourishing among Nigerian miliraty personnel's. Nigerian Journal of Psychological Research, 2019; $15,39-45$.

30. Katsina AM. A Critical Analysis of the Nigeria's Defence Policy in the Fourth Republic 1999-2007. A Thesis submitted as part of the necessary requirements for the award of Msc. (Degree) in Defence and Strategic Studies. Nigerian Defence Academy (NDA), Kaduna, 2008. 2008.

31. Olukolade C. Lack of synergy among security, intelligence agencies unhealthy. Metrowatch, June 19. 2017. http://metrowatchonline.com/lacksynergy-among-security-intelligence-agenciesunhealthy-says-olukolade/. Accessed 19 June, 2020.

32. Eneche J. 603 repentant Boko Haram fighters to be reintegrated into communities. Premium Times.
2020.

https://www.premiumtimesng.com/news/headlines 1397187-603-repentant-boko-haram-fighters-tobe-reintegrated-into-communities.html. Assessed 17th June, 2020.

33. Muraina AI. Changing roles of the Nigerian armed forces and funding implications. Gold press limited, Ibadan. 2011.

34. Omede AJ. The Nigerian Military: Analyzing fifty years of defense and internal military and fifty years of internal security operations in Nigeria (1960-2010). Journal of Social Science, 2012; 33(3), 293-303.

35. Jiang Z. The relationship between career adaptability and job content plateau: The mediating roles of fit perceptions. Journal of Vocational Behavior, 2016; 95-96, 1-10.

36. Männiste T, Pedaste M, Schimanski R. Situational judgment test for measuring military tactical decision-making skills. Military Psychology, 2019; 1-12. doi:10.1080/08995605.2019.1664366

37. Hirschi A, Valero D. Career adaptability profiles and their relationship to adaptively and adapting. Journal of Vocational Behavior, 2015; 88, 220229.

38. Oh IS, Guay RP, Kim K, Harold CM, Lee JH, Heo CG, Shin KH. Fit happens globally: A metaanalytic comparison of the relationships of personenvironment fit dimensions with work attitudes and performance across East Asia, Europe, and North America. Personnel Psychology, 2014; 67(1), 99-152.

39. Rudolph CW, Lavigne KN, Zacher H. Career adaptability: A meta-analysis of relationships with measures of adaptively, adapting responses, and adaptation results. Journal of Vocational Behavior, 2017; 98, 17-34.

40. Vleugels W, Tierens H, Billsberry J, Verbruggen M, De Cooman R. Profiles of fit and misfit: a repeated weekly measures study of perceived value congruence. European Journal of Work and Organizational Psychology, 2019; 8(5), 1-15. 